\begin{tabular}{|l|l|l|}
\hline \multicolumn{2}{|c|}{ PublisherInfo } \\
\hline \hline PublisherName & $:$ & BioMed Central \\
\hline \hline PublisherLocation & $:$ & London \\
\hline \hline PublisherImprintName & $:$ & BioMed Central \\
\hline \hline
\end{tabular}

\title{
Keeping an eye on gene expression
}

\begin{tabular}{|l|l|l||}
\hline \multicolumn{2}{|c|}{ ArticleInfo } \\
\hline \hline ArticleID & $:$ & 4375 \\
\hline \hline ArticleDOI & $:$ & $10.1186 /$ gb-spotlight-20020114-01 \\
\hline \hline ArticleCitationID & $:$ & spotlight-20020114-01 \\
\hline \hline ArticleSequenceNumber & $:$ & 41 \\
\hline \hline ArticleCategory & $:$ & Research news \\
\hline \hline ArticleFirstPage & $:$ & 1 \\
\hline \hline ArticleLastPage & $:$ & 2 \\
\hline \hline & & RegistrationDate : 2002-01-14 \\
ArticleHistory & $:$ & OnlineDate $\quad:$ 2002-01-14 \\
\hline \hline ArticleCopyright & $:$ & BioMed Central Ltd2002 \\
\hline \hline ArticleGrants & $:$ & \\
\hline \hline ArticleContext & $:$ & 130593311 \\
\hline \hline
\end{tabular}




\section{Jonathan B Weitzman}

Email: jonathanweitzman@hotmail.com

The retina contains neuronal cells (including photoreceptors) and non-neuronal retinal pigment epithelium (RPE). In the January 8 issue of Proceedings of the National Academy of Sciences, Dror Sharon and colleagues at Harvard Medical School describe characterization of gene expression profiles in the human eye using the SAGE (serial analysis of gene expression) technology (Proc Natl Acad Sci USA 2002, 99:315-320). They prepared SAGE libraries from the peripheral retina, the macula and the RPE of two individuals (an 88 year-old woman and a 44 year-old man) and examined over 320,000 SAGE tags. They found a large number of unassigned tags in the RPE library (38\%) suggesting tissuespecific expression. The genes most highly expressed in the retina include several encoding proteins involved in phototransduction and energy metabolism. The RPE pattern differed from that of the neural retina and included many genes involved in protein degradation and translation. Sharon et al.found evidence for age-related gene expression differences between the two patients; for example, the older donor expressed fewer genes specific for rod photoreceptors. Characterization of genes expressed in specific areas within the human eye will help identify genes related to retinal diseases.

\section{References}

1. Proceedings of the National Academy of Sciences, [http://www.pnas.org]

2. Harvard Medical School , [http://www.hms.harvard.edu]

3. Analysing uncharted transcriptomes with SAGE.

4. SAGE, [http://www.ncbi.nlm.nih.gov/SAGE] 